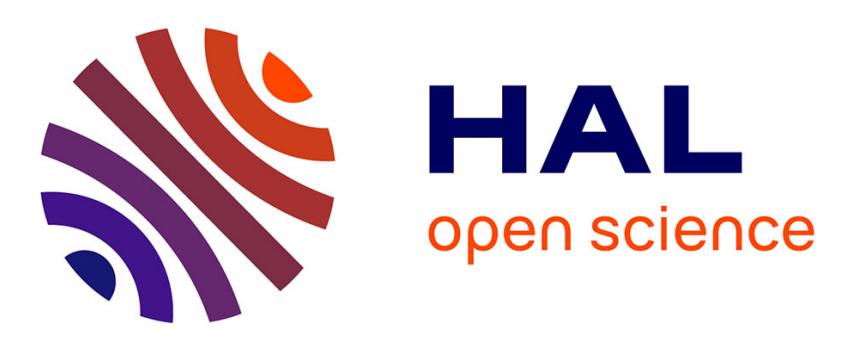

\title{
Transient fertilizing effect of dust in P-deficient LNLC surface ocean
}

\author{
Elvira Pulido-Villena, Victoire Rerolle, Cecile Guieu
}

\section{To cite this version:}

Elvira Pulido-Villena, Victoire Rerolle, Cecile Guieu. Transient fertilizing effect of dust in P-deficient LNLC surface ocean. Geophysical Research Letters, 2010, 37, pp.L01603. 10.1029/2009GL041415 . hal-00691392

\section{HAL Id: hal-00691392 \\ https://hal.science/hal-00691392}

Submitted on 9 Apr 2021

HAL is a multi-disciplinary open access archive for the deposit and dissemination of scientific research documents, whether they are published or not. The documents may come from teaching and research institutions in France or abroad, or from public or private research centers.
L'archive ouverte pluridisciplinaire HAL, est destinée au dépôt et à la diffusion de documents scientifiques de niveau recherche, publiés ou non, émanant des établissements d'enseignement et de recherche français ou étrangers, des laboratoires publics ou privés. 


\title{
Transient fertilizing effect of dust in P-deficient LNLC surface ocean
}

\author{
Elvira Pulido-Villena, ${ }^{1}$ Victoire Rérolle, ${ }^{1}$ and Cécile Guieu ${ }^{1}$ \\ Received 19 October 2009; accepted 30 November 2009; published 14 January 2010.
}

[1] In much of the world's low-nutrient low-chlorophyll (LNLC) oceans, including the Mediterranean Sea, surface dissolved inorganic phosphorus (DIP) is below the detection limit of conventional techniques. Although dust deposition has been generally recognized as a major source of $\mathrm{P}$ to the Mediterranean Sea, the lack of DIP data at nanomolar levels has so far precluded a quantification of this effect. This work reports the first one-year time series of surface nanomolar DIP in the Mediterranean Sea. Moreover, by combining nanomolar DIP data from two field studies (the above cited time-series and an experimental addition of Saharan dust to large mesocosms) and one in vitro dust dissolution experiment, we show that dust pulses may indeed provoke transient increases in DIP concentration (up to $80 \mathrm{nM}$ ) in P-starved surface waters of this LNLC region. Citation: Pulido-Villena, E., V. Rérolle, and C. Guieu (2010), Transient fertilizing effect of dust in P-deficient LNLC surface ocean, Geophys. Res. Lett., 37, L01603, doi:10.1029/ 2009GL041415.

\section{Introduction}

[2] There is growing awareness of the P deficiency in certain regions of the oligotrophic ocean. Studies in the North Pacific Sub-tropical gyre [Karl et al., 2001 and references therein] and North Atlantic Sub-tropical gyre [Wu et al., 2000; Ammerman et al., 2003] have used high quality measurements to reveal concentrations of dissolved inorganic phosphorus (DIP) as low as $0.5 \mathrm{nM}$. Despite cited efforts, DIP data at nanomolar levels remain scarce mainly due to the coarse detection limit of the conventional techniques of analysis used ( $30 \mathrm{nM}$ at best cases). Introduction of the magnesium induced co-precipitation method (MAGIC) substantially improved the amount of DIP data at nanomolar levels [e.g., Rimmelin and Moutin, 2005]. However, the laborious and time-consuming manipulation of the samples in combination with the contamination risks and the high volume of sample required has precluded the routine utilization of this technique. The recently introduced technique of the long liquid waveguide capillary cell (LWCC) [Zhang and Chi, 2002; Patey et al., 2008] provides an easy and efficient alternative for DIP nanomolar measurements and has been successfully applied in a number of field studies [e.g., Krom et al., 2005].

[3] Atmospheric input of nutrients to marine systems associated with dust deposition has received great attention, particularly in HNLC (high nutrient-low chlorophyll) open ocean regions, where dust can be the main external source

\footnotetext{
${ }^{1}$ Laboratoire d'Océanographie de Villefranche, Université Paris VI, UMR7093, CNRS, Villefranche-sur-Mer, France.
}

Copyright 2010 by the American Geophysical Union. 0094-8276/10/2009GL041415\$05.00 of iron [Jickells et al., 2005]. In low nutrient-low chlorophyll (LNLC) regions, the fertilizing potential of mineral particles remains less explored and poorly understood. Dust inputs have been hypothesized to be responsible for the phosphate deficiency in several LNLC regions. Indeed those areas receiving important inputs of iron-rich dust exhibit elevated rates of $\mathrm{N}_{2}$ fixation. This, in turn, increases the $\mathrm{N}$ pool and pushes the system toward P limitation [Wu et al., 2000]. This hypothesis would explain why the North Atlantic tropical gyre (highly affected by Saharan dust deposition) shows lower phosphate concentrations than its southern counterpart [Mather et al., 2008]. Besides containing iron, Saharan dust contains particulate $\mathrm{P}$ [Guieu et al., 2002] and it may hence deliver significant amounts of $P$ to the surface waters of the LNLC regions. This P source has been demonstrated both through field data on $\mathrm{P}$ atmospheric fluxes associated to dust events [e.g., Bergametti et al., 1992] and through in vitro dissolution experiments of aerosols in seawater [Ridame and Guieu, 2002; Baker et al., 2006]. However, the potential release of DIP from dust in surface oligotrophic waters occurs at nanomolar levels and hence, methodological limitations have so far precluded the quantification of the fertilizing potential of mineral dust in these P-starved oceanic systems.

[4] The goal of this work was to quantify the fertilizing potential of dust inputs in the P-starved surface waters of the LNLC Mediterranean Sea. For this purpose we combined data obtained from two field studies (a one-year time-series and an experimental addition of Saharan dust to large mesocosms) and one laboratory in vitro dust dissolution experiment. The combination of these three approaches shed valuable light on how dust inputs can provoke transient changes in DIP availability in the LNLC surface ocean.

\section{Material and Methods}

\subsection{One-Year Time-Series of Surface Dissolved Inorganic Phosphorus}

[5] Seawater was collected monthly between December 2005 and December 2006 on board the R/V Tethys II at the permanent time-series DYFAMED site $\left(43^{\circ} 25^{\prime} \mathrm{N}, 7^{\circ} 52^{\prime} \mathrm{E}\right)$. Filtered seawater $(<0.2 \mu \mathrm{m}$, Sartobran cartridge filter) was collected for dissolved inorganic phosphorus (DIP) analysis in duplicate at five different depths (surface, 5, 10, 20 and $40 \mathrm{~m}$ ) using a trace metal-clean Teflon pump system. Samples were stored frozen until analysis. Seawater samples were unfrozen and acidified with $\mathrm{HCl}$ (Suprapur quality, final concentration $1: 1000 \mathrm{v}: \mathrm{v}) 24$ hours prior to analysis.

\subsection{Mesocosm Experiment}

[6] An experimental dust addition onto large mesocosms $\left(54 \mathrm{~m}^{3}, 15-\mathrm{m}\right.$ depth) was conducted in June 2008 in the NW 

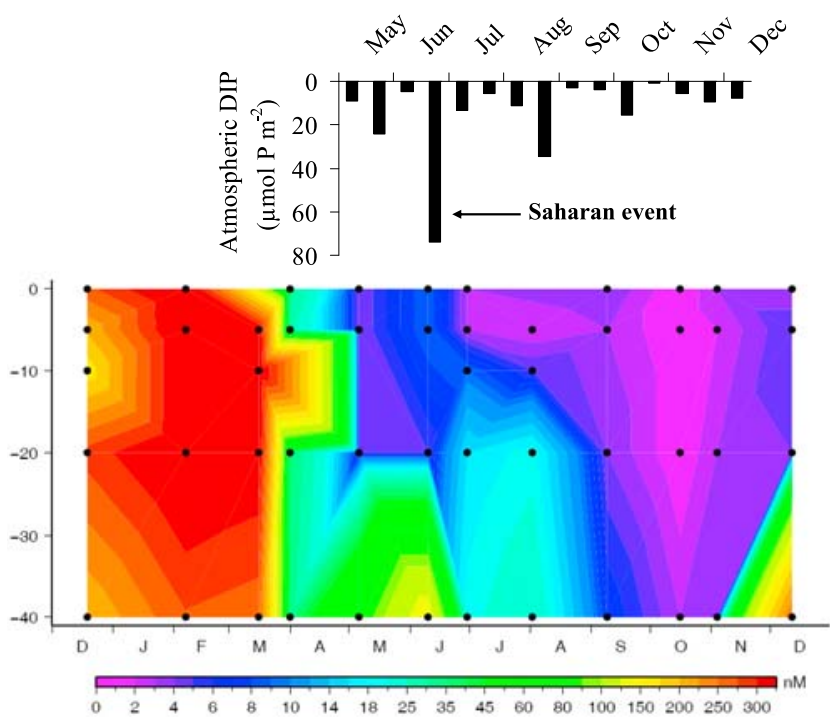

Figure 1. (bottom) Dissolved inorganic phosphorus (DIP, nmol $\mathrm{P} \mathrm{L}^{-1}$ ) in the $0-40 \mathrm{~m}$ depth layer between December 2005 and December 2006 at the DYFAMED site. Points represent sampling depths. (top) Atmospheric input of DIP $\left(\mu \mathrm{mol} \mathrm{P} \mathrm{m}{ }^{-2}\right)$ in the study region during the stratification period (May-December 2006) reported by Pulido-Villena et al. [2008].

Mediterranean Sea in the frame of the ANR-DUNE project (www.obs-vlfr.fr/LOV/DUNE). A detailed description of the experiment is given by Guieu [2009] (see auxiliary material). ${ }^{1}$ Briefly, three replicate mesocosms (hereafter referred to as 'D-mesocosms') were amended with $41 \mathrm{~g}$ of mineral dust reproducing a realistic atmospheric dust deposition of $10 \mathrm{~g} \mathrm{~m}^{-2}$. The dust used results from Saharan soils submitted to mechanical and physicochemical transformations mimicking atmospheric transport [Desboeufs et al., 2001; Tran, 2008]. Three other mesocosms (hereafter referred to as 'C-mesocosms') served as controls. Samples from the six mesocosms were taken just before the dust addition and at regular intervals during 8 days starting 6 hours after the amendment. Seawater was also collected outside the mesocosms (hereafter referred to as 'OUT') at selected times during the experiment in order to check for contamination inside the mesocosms. Filtered seawater $(<0.2 \mu \mathrm{m}$, Sartobran cartridge filter) was collected for DIP analysis at surface, 5 and $10 \mathrm{~m}$ depth using a trace metalclean Teflon pump system. Samples were analyzed immediately after collection.

\subsection{In Vitro Dissolution Experiment}

[7] One dissolution experiment was performed by adding dust to $0.2 \mu \mathrm{m}$-filtered seawater to a final concentration of $1.2 \mathrm{mg} \mathrm{L}^{-1}$. The main goal of this abiotic experiment was to reproduce a pulsed dust input into the surface mixed layer (SML) during the stratification period. In order to compare the results obtained with those from the mesocosm exper-

\footnotetext{
${ }^{1}$ Auxiliary materials are available in the HTML. doi:10.1029/ 2009GL041415.
}

iment, the seawater was collected at the mesocosm site ('OUT') and the dust used was the same as for the mesocosm experiment. The chosen concentration tempted to mimic the $10 \mathrm{~g} \mathrm{~m}^{-2}$ flux of dust in the mesocosm assuming a homogeneous distribution of the particles within the SML. The experiment was performed in triplicate and three unamended flasks served as controls. Subsamples were taken from the six experimental flasks before the addition of dust and after a contact time of 6 hours. The samples were filtered onto $0.2 \mu \mathrm{m}$ polycarbonate filters and analyzed immediately for DIP concentration.

\subsection{Nanomolar DIP Measurements}

[8] DIP in the three studies described above was analyzed by spectrophotometry [Murphy and Riley, 1962; Zhang and Chi, 2002] using a long waveguide capillary cell (LWCC). In the recent years, a number of studies focusing on the analytical accuracy of the LWCC technique for measuring DIP have demonstrated a good agreement with the MAGIC technique [Li and Hansell, 2008] and negligible interference with arseniate and silicate [Li and Hansell, 2008; Ma et al., 2009]. In the time-series and the in vitro experiments, the LWCC was 2-m long (limit of detection, LOD = three times the standard deviation of 10 measurements of the blank = $1 \mathrm{nM})$. For the mesocosm experiment, the LWCC was $1-\mathrm{m}$ long $(\mathrm{LOD}=2 \mathrm{nM})$. More details on the analytical procedure can be found as auxiliary material.

\section{Results}

\subsection{One-Year Time-Series of Surface Dissolved Inorganic Phosphorus}

[9] This study presents the first one-year time-series of DIP in surface waters of the LNLC Mediterranean Sea (Figure 1). During the winter mixing period (December 2005-March 2006), DIP ranged between 200 and $350 \mathrm{nM}$ and it decreased to values around $30 \mathrm{nM}$ in April 2006, after the phytoplankton spring bloom. The stratification period (May 2006-December 2006) was characterized by DIP values between 6 and $1 \mathrm{nM}$ at depths above $20 \mathrm{~m}$. During this period, DIP above the mixed layer depth $(8-20 \mathrm{~m}$ depth) remained low and relatively constant despite the continuous DIP inputs from the atmosphere reported for that period by Pulido-Villena et al. [2008]. In particular, no changes in surface DIP were observed one week after a Saharan dust event registered on June 2006 which delivered a DIP flux of $74 \mu \mathrm{mol} \mathrm{P} \mathrm{m}{ }^{-2}$ (Figure 1).

\subsection{Mesocosm Experiment}

[10] DIP in OUT and C-mesocosms ranged between 2 and $6 \mathrm{nM}$ over the duration of the experiment (Figure 2). In the D-mesocosms, DIP before the addition was $4 \pm 1 \mathrm{nM}$. Six hours after the addition, surface DIP increased in all three mesocosms to $17 \pm 4 \mathrm{nM}$. No increase was observed at 5 and $10-\mathrm{m}$ depth. Surface DIP decreased to initial values in the subsequent sampling (24 hours after the seeding) and remained constant until the end of the experiment (Figure 2).

\subsection{In Vitro Dissolution Experiment}

[11] DIP in the experimental flasks before the dust amendment was $5 \pm 1 \mathrm{nM}$. After a contact time of 6 hours, DIP in the amended treatment increased significantly to 

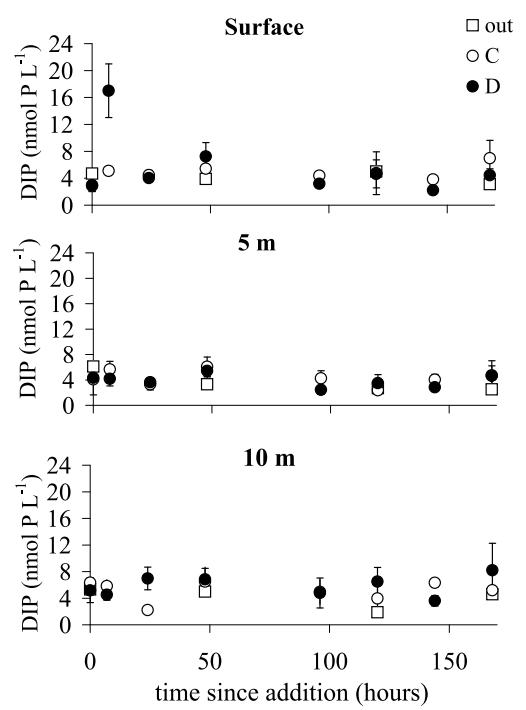

Figure 2. Concentration of dissolved inorganic phosphorus (DIP, nmol $\mathrm{P} \mathrm{L}^{-1}$ ) during of the DUNE mesocosm experiment in OUT, C-mesocosms and D-mesocosms at surface, $5-\mathrm{m}$ and $10-\mathrm{m}$ depth. OUT values represent the average and standard deviation of two replicate samples. $\mathrm{C}$ - and D-mesocosms values represent the average and standard deviation of the three replicate mesocosms.

$10 \pm 1 \mathrm{nM}$ whereas it remained constant in the control flasks.

\section{Discussion}

\subsection{P-Deficiency in Surface Waters} of the Mediterranean Sea

[12] The limitation of biological activity by $\mathrm{P}$ in the stratified surface waters of the Mediterranean Sea has been extensively reported [e.g., Thingstad et al., 1998]. The stratification period has been usually represented by a gap in which DIP values were below the detection limit [e.g., Marty et al., 2002]. Moutin et al. [2002] attempted for the first time to estimate the concentration of bioavailable phosphate in the western Mediterranean Sea through measurements of P-uptake. Their results showed estimated concentrations of $3 \mathrm{nmol} \mathrm{L}^{-1}$, similar to measured DIP values in this study. In the eastern Mediterranean Sea, DIP values obtained during the CYCLOPS cruise in May 2003 were $<2-4 \mathrm{nM}$ [Krom et al., 2005], slightly lower than observed in May in this study. Regarding other LNLC regions, our surface DIP data are in the same order of magnitude as those reported for the western North Atlantic (from 0.4 to $3.9 \mathrm{nM}$ ) and lower than in the subtropical North Pacific $(13 \pm 2 \mathrm{nM})$ [Wu et al., 2000]. Our DIP values, together with literature data, confirm that surface DIP in several LNLC regions, during at least 6 months of the year, is low enough to result in P control of biological activity.

\subsection{Linking Fertilizing Potential of Mineral Dust and Particle Vertical Distribution}

[13] Episodic P-rich dust inputs to the surface Mediterranean waters can be the only source of nutrients to the surface mixed layer (SML) during the stratification period [e.g., Bergametti et al., 1992]. The results from the meso- cosm experiment provide a quantitative confirmation of this fertilizing potential of mineral dust. The C-mesocosms reflected the observed situation in the DYFAMED site during the stratification period of 2006: DIP values that remained low without significant variations over the duration of the experiment. In the D-mesocosms, a DIP release from the dust was observed soon after the seeding and it produced a 3-fold increase in surface DIP. This result contrasts with the decrease observed in dissolved Fe concentration after the seeding which was likely transferred to the particulate phase [Guieu, 2009]. No significant correlation was found between surface DIP and $\mathrm{dFe}$ over the duration of the experiment $(n=8 ; r=-0.38 ; p=0.354)$.

[14] The release of DIP from dust will be dependent on the fraction of the total $\mathrm{P}$ content that get dissolved in seawater upon deposition. Ridame and Guieu [2002] showed that the percentage of dissolution decreases as the particle concentration $(\mathrm{Pc})$ increases and reported a negative power relationship between both variables for a contact time of 6 hours. This relationship may have critical consequences on the fertilizing potential of mineral dust which will ultimately depend on particle vertical distribution within the water column. Dust deposited on the surface ocean is often assumed to distribute homogeneously within the SML [e.g., Blain et al., 2004]. In the mesocosm experiment, this assumption would lead to a Pc of $1.2 \mathrm{mg} \mathrm{L}^{-1}$. However, when performing the abiotic dissolution experiment at that Pc, the DIP released was lower than observed in the mesocosm experiment. This discrepancy suggests a nonhomogeneous vertical distribution of the mineral particles in the mesocosm which agrees with the fact that the DIP increase was only observed in the surface. The percentage of dissolution calculated from the abiotic dissolution experiment for a Pc of $1.2 \mathrm{mg} \mathrm{L}^{-1}$ and a contact time of 6 hours is $35 \%$ of dust total $\mathrm{P}$ content. This percentage is consistent with the relationship reported by Ridame and Guieu [2002] (Figure 3), which may thus be used to calculate the Pc needed to explain the DIP increase in the mesocosms experiment. This back-calculation leads to a Pc of $29 \mathrm{mg} \mathrm{L}^{-1}$, one order of magnitude higher than predicted under the assumption of a homogeneous vertical distribution of the Saharan particles over the SML. Considering the total amount of dust added

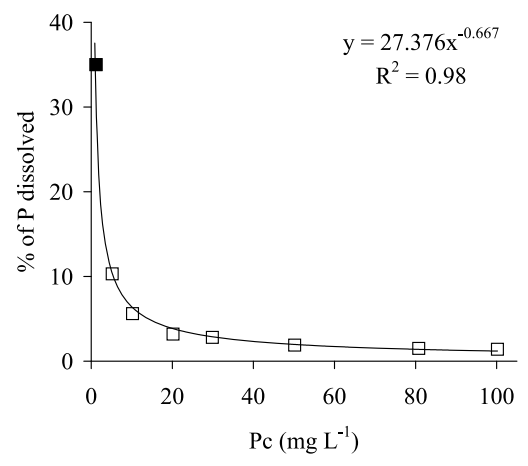

Figure 3. Percentage of dissolved inorganic phosphorus released from dust in seawater as a function of particle concentration (Pc) for a contact time of 6 hours. The white squares (data for particle concentrations between 5 and $100 \mathrm{mg} \mathrm{L}^{-1}$ ) and the power relationship are reported by Ridame and Guieu [2002]. Black square $\left(\mathrm{Pc}=1.2 \mathrm{mg} \mathrm{L}^{-1}\right)$, this study. 
to the mesocosms, such a concentration would have been achieved after a distribution of the added particles within the top $40 \mathrm{~cm}$ of the water column. We thus hypothesize that most of the added particles remained in the surface during the first hours of the experiment leading to observed increase in surface DIP.

[15] This hypothesis was applied to predict the increase in surface DIP in the DYFAMED site after the dust event of June 2006. Under the assumption of a homogeneous vertical distribution of particles within the SML, this dust event would have induced a transient increase in DIP of $10 \mathrm{nM}$ [Pulido-Villena et al., 2008] over the whole SML. By contrast, applying a conservative vertical distribution of dust particles within the top meter, the dust event would produce an increase in surface DIP of $80 \mathrm{nM}$. These estimates underline the need for a better understanding of the vertical distribution of dust particles within the water column upon deposition in order to quantify their potential to fertilize oceanic surface waters. Moreover, our results suggest that in vitro approaches, which rely upon a fixed and homogeneously distributed concentration of particles, can lead to inaccurate estimates of the DIP release from mineral dust and their extrapolation to natural conditions must be performed very cautiously.

\subsection{Bioavailability of Dust-Derived $P$}

[16] The DIP released from the mineral dust in the mesocosm experiment was completely lost after 24 hours and no further increase was observed during the experiment. A physical loss by dilution, typical of large-scale fertilization experiments [e.g., Law et al., 2005], is unlikely in this particular case given the nature of the experiments which enclose the water column precluding horizontal diffusion. For its part, adsorption onto the added dust would have had negligible contribution to the observed decrease in DIP. According to reported DIP adsorption capacity of Saharan dust (e.g., $0.13 \mu \mathrm{mol} \mathrm{g}^{-1}$ ) [Ridame et al., 2003], between 0.2 and $3.5 \mathrm{nM}$ would have been transferred to the particulate phase for a Pc of 1.2 and $29 \mathrm{mg} \mathrm{L}^{-1}$, respectively. DIP loss might have been thus dominated by biological uptake in agreement with the observed rapid response of both bacteria and phytoplankton [Guieu, 2009]. A rapid biological uptake of dust-derived DIP would also explain the lack of DIP increase observed at the DYFAMED site one week after the dust event of June 2006 (Figure 1). These results suggest that dust-derived DIP is biologically available and it can transiently relieve P-limitation inducing pulsed enhancements of biological activity.

\subsection{Biogeochemical Consequences of Dust Deposition in LNLC Regions}

[17] Much effort is being put forth to evaluate the biogeochemical consequences of dust-derived iron inputs in high nutrient-low chlorophyll (HNLC) regions. The data presented in this work highlight the significance of dust as a source of $\mathrm{P}$ to the Mediterranean Sea, a LNLC region exhibiting a severe P-deficiency during the stratification period. Although dust deposition may push LNLC regions towards $\mathrm{P}$ limitation over a large time scale as a result of iron-enhanced $\mathrm{N}_{2}$ fixation, this study indicates that it can also provoke transient increases in $\mathrm{P}$ availability and may thus stimulate the growth of P-limited communities.
[18] Acknowledgments. This work was supported by the Institut National des Sciences de l'Univers (INSU) and the Centre National de la Recherche Scientifique (CNRS) in the frame of the ANR programs BOA and DUNE. A postdoctoral fellowship from the Spanish Ministerio de Educacion y Ciencia and the ANR DUNE supported EPV. We thank J. C. Marty and L. Coppola, responsible for the French DYFAMED time-series program, and the captain and crew of the French R/V Tethys for their cooperative work at sea. Authors also wish to warmly thank J. M. Dominici and his team at the Scandola Preservation Area for their logistical support and their help during the DUNE campaign. The ANR-DUNE project is endorsed by the International SOLAS (Surface Ocean-Lower Atmosphere Study) Project. We thank N. Mladenov, who kindly checked the manuscript for scientific English, and E. Achterberg, whose review greatly helped to improve the manuscript. The authors appreciate the constructive remarks of the editor, M. Srokosz.

\section{References}

Ammerman, J. W., R. R. Hood, D. A. Case, and J. B. Cotner (2003), Phosphorus deficiency in the Atlantic: An emerging paradigm in oceanography, Eos Trans. AGU, 84(18), doi:10.1029/2003EO180001.

Baker, A. R., M. French, and K. L. Linge (2006), Trends in aerosol nutrient solubility along a west-east transect of the Saharan dust plume, Geophys. Res. Lett., 33, L07805, doi:10.1029/2005GL024764.

Bergametti, G., E. Remoudaki, R. Losno, E. Steiner, and B. Chatenet (1992), Source, transport and deposition of atmospheric phosphorus over the northwestern Mediterranean, J. Atmos. Chem., 14, 501-513, doi:10.1007/BF00115254.

Blain, S., C. Guieu, H. Claustre, K. Leblanc, T. Moutin, B. Queguiner, J. Ras, and G. Sarthou (2004), Availability of iron and major nutrients for phytoplankton in the northeast Atlantic Ocean, Limnol. Oceanogr., 49, 2095-2104

Desboeufs, K. V., R. Losno, and J. L. Colin (2001), Factors influencing aerosol solubility during cloud process, Atmos. Environ., 35, 3529-3537, doi:10.1016/S1352-2310(00)00472-6.

Guieu, C. (2009), DUNE: A DUst experiment in a low-Nutrient low chlorophyll Ecosystem, SOLAS Newsl., 9, 36-37.

Guieu, C., M. D. Loye-Pilot, C. Ridame, and C. Thomas (2002), Chemical characterization of the Saharan dust end-member: Some biogeochemical implications for the western Mediterranean Sea, J. Geophys. Res., 107(D15), 4258, doi:10.1029/2001JD000582.

Jickells, T. D., et al. (2005), Global iron connections between desert dust, ocean biogeochemistry, and climate, Science, 308, 67-71, doi:10.1126/ science. 1105959 .

Karl, D. M., K. M. Bjorkman, J. E. Dore, L. Fujieki, D. V. Hebel, T. Houlihan, R. M. Letelier, and L. M. Tupas (2001), Ecological nitrogen-to-phosphorus stoichiometry at station ALOHA, Deep Sea Res., Part II, 48, 1529-1566, doi:10.1016/S0967-0645(00)00152-1.

Krom, M. D., et al. (2005), Nutrient cycling in the south east Levantine basin of the eastern Mediterranean: Results from a phosphorus starved system, Deep Sea Res., Part II, 52, 2879-2896, doi:10.1016/ j.dsr2.2005.08.009.

Law, C. S., E. R. Abraham, E. M. S. Woodward, M. I. Liddicoat, T. W. Fileman, T. F. Thingstad, V. Kitidis, and T. Zohary (2005), The fate of phosphate in an in situ Lagrangian addition experiment in the eastern Mediterranean, Deep Sea Res., Part II, 52, 2911-2927, doi:10.1016/ j.dsr2.2005.08.017.

Li, Q. P., and D. A. Hansell (2008), Intercomparison and coupling of magnesium-induced co-precipitation and long-path liquid-waveguide capillary cell techniques for trace analysis of phosphate in seawater, Anal. Chim. Acta, 611, 68-72, doi:10.1016/j.aca.2008.01.074.

Ma, J., D. Yuan, M. Zhang, and Y. Ling (2009), Reverse flow injection analysis of nanomolar soluble reactive phosphorus in seawater with a long path length liquid waveguide capillary cell and spectrophotometric detection, Talanta, 78, 315-320, doi:10.1016/j.talanta.2008.11.017.

Marty, J.-C., J. Chiaverini, M.-D. Pizay, and B. Avril (2002), Seasonal and interannual dynamics of nutrients and phytoplankton pigments in the western Mediterranean Sea at the DYFAMED time-series station (1991-1999), Deep Sea Res., Part II, 49, 1965-1985, doi:10.1016/ S0967-0645(02)00022-X.

Mather, R. L., S. E. Reynolds, G. A. Wolff, R. G. Williams, S. TorresValdes, E. M. S. Woodward, A. Landolfi, X. Pan, R. Sanders, and E. P. Achterberg (2008), Phosphorus cycling in the North and South Atlantic Ocean subtropical gyres, Nature Geosci., 1, 439-443, doi:10.1038/ ngeo232.

Moutin, T., T. F. Thingstad, F. Van Wambeke, D. Marie, G. Slawyk, P. Raimbault, and H. Claustre (2002), Does competition for nanomolar phosphate supply explain the predominance of the cyanobacterium Synechococcus? Limnol. Oceanogr., 47, 1562-1567. 
Murphy, J., and J. Riley (1962), A modified single solution method for the determination of phosphate in natural waters, Anal. Chim. Acta, 27, $31-$ 36, doi:10.1016/S0003-2670(00)88444-5.

Patey, M. D., M. J. A. Rijkenberg, P. J. Statham, M. C. Stinchcombe, E. P. Achterberg, and M. Mowlem (2008), Determination of nitrate and phosphate in seawater at nanomolar concentrations, Trends Anal. Chem., 27, $169-182$.

Pulido-Villena, E., T. Wagener, and C. Guieu (2008), Bacterial response to dust pulses in the western Mediterranean: Implications for carbon cycling in the oligotrophic ocean, Global Biogeochem. Cycles, 22, GB1020, doi:10.1029/2007GB003091.

Ridame, C., and C. Guieu (2002), Saharan input of phosphate to the oligotrophic water of the open western Mediterranean Sea, Limnol. Oceanogr., 47, 856-869.

Ridame, C., T. Moutin, and C. Guieu (2003), Does phosphate adsorption onto Saharan dust explain the unusual N/P ratio in the Mediterranean Sea?, Oceanol. Acta, 26, 629-634, doi:10.1016/S0399-1784(03)00061-6.

Rimmelin, P., and T. Moutin (2005), Re-examination of the MAGIC method to determine low orthophosphate concentration in seawater, Anal. Chim. Acta, 548, 174-182, doi:10.1016/j.aca.2005.05.071.
Thingstad, T. F., U. L. Zweiful, and F. Rassoulzadegan (1998), P limitation of heterotrophic bacteria and phytoplankton in the northwest Mediterranean, Limnol. Oceanogr., 43, 88-94.

Tran, S. (2008), Caractérisation des sources de poussières désertiques influençant le bassin Méditerranéen Occidental dans le cadre de la campagne DUNE, M.S. thesis, Univ. de Paris XII, Paris.

Wu, J. F., W. Sunda, E. A. Boyle, and D. M. Karl (2000), Phosphate depletion in the western North Atlantic Ocean, Science, 289, 759-762, doi:10.1126/science.289.5480.759.

Zhang, J. Z., and J. Chi (2002), Automated analysis of nanomolar concentrations of phosphate in natural waters with liquid waveguide, Environ Sci. Technol., 36, 1048-1053, doi:10.1021/es011094v.

C. Guieu, E. Pulido-Villena, and V. Rérolle, Laboratoire d'Océanographie de Villefranche, Université Paris VI, UMR7093, CNRS, Chemin du Lazaret, F-06234 Villefranche-sur-Mer, France. (pulido-villena@obsvlfr.fr) 